\title{
Clone x Tester Crosses on Compatibility Level of Sweetpotato (Ipomoea batatas L.)
}

\author{
Febria C. Indriani ${ }^{1}$, Joko Restuono ${ }^{1}$, Wiwit Rahajeng ${ }^{1}$, Rudi Iswanto $^{1}$, \\ Titik Sundari ${ }^{1}$, Rudy Soehendi ${ }^{1}$,Didik Harnowo ${ }^{1}$,Yuliantoro Baliadi ${ }^{1}$ \\ and Made J. Mejaya ${ }^{{ }^{*}}$ \\ ${ }^{1}$ Indonesian Legumes and Tuber Crops Research Institute (ILETRI), Jl. Raya Kendalpayak Km.8, \\ P.O.Box 66 Malang 65101, East Java, Indonesia.
}

Authors' contributions

This work was carried out in collaboration among all authors. Authors $F C I, R I, Y B$ and TS designed the study. Authors $\mathrm{JR}, W R$ and $\mathrm{FCl}$ performed the statistical analysis and wrote the protocol. Authors $\mathrm{FCl}, \mathrm{DH}$ and MJM wrote the first draft of the manuscript. Authors TS and MJM managed the analyses of the study. Authors FCl, RS and DH managed the literature searches. All authors read and approved the final manuscript.

Article Information

DOI: $10.9734 / A R R B / 2021 / v 36 i 530372$

(1) Dr Paola Angelini, University of Perugia, Italy. Reviewers:

(1) Monier Morad Wahba, National Research Centre. Egypt. (2) Rudy Hartono, Makassar of Health Polytechnic the Ministry of Health, Indonesia. Complete Peer review History: http://www.sdiarticle4.com/review-history/68071

Original Research Article

Received 06 March 2021

Accepted 12 May 2021

Published 26 May 2021

\begin{abstract}
Evaluation of compatibility on sweetpotato is very important to determine the crossing parents to increase the compatibility of controlled cross-pollination. This research was aimed to study the level of compatibility in controlled cross-pollination based on percentage of normal seedlings obtained from crosses. The research was conducted at Kendalpayak Experimental Station of ILETRI, Malang, Indonesia then followed by breaking seed dormancy and germination of seeds obtained. The genetic materials used were 17 accessions with high yielding potential and 3 accessions as tester for crossing. The results showed that there were differences in the compatibility levels of crossing combination and their compatibilities as male or female parents. Clone C-011 (Tester 2) was the most compatible as male parent, while clone C-141, C- 007 and C-131 were the most compatible as female parents. Clone C-127 (Tester 3) was the most compatible as both male and female parents. Clone C-001 (Tester 1) could not be used as female parent due to high incompatibility. This compatible clone information is very useful in determining of both controlled crosses and open crosses in sweet potato in order to increase the breeding efficiency.
\end{abstract}


Keywords: Compatibility; crossing; seedlings; sweetpotato; tester.

\section{INTRODUCTION}

New genetic diversity can be developed through controlled crosses and open crosses. Populations resulting from sweet potato (Ipomoea batatas L.) crossing among different clones will have high heterosigosity. Parents having the characteristics of self-incompatibility, cross-incompatibility and sterility lead to very low success of crosses. The flowering ability of each clone varies, even some clones were difficult to flower. The balance of the flowering ability of the parents of the crosses was highly required for open pollination(polycross) or hand pollination (controlled crosses)[1].

Sweet potato has chromosome $2 \mathrm{n}=6 \mathrm{x}=90$, have two types of chromosomes based on compatibility, namely: group A consist of species that were of the nature of species self-compatible (SC): Ipomoea lacunose, Ipomoea triloba, Ipomoea trichocarpa, Ipomoea tiliaceae and Ipomoea gracilis, grup B consist of/pomoea trifida, Ipomoea litoralis and Ipomoea batatas[2]. Species in group B have a sporophytic SI type, a self-incompatible system that occurs when pollen falls on the pistil, but pollen does not occur so that fertilization does not occur and fertilization does not occur [3]. Meanwhile, if cross pollination and compatibility were carried out, pollen germination will occur 10-20 minutes after pollination [4].

Selfing (self-pollination on one plant) generally causes sterility, only a few clones were fertile [5]. There were two types of sterility in sweet potatoes, namely: (a). Sterility occurs in the prepollination phase, sterile pollen was found due to the disruption of the process of meiosis that produces gametes that were not viable and not functional, and (b) sterility occurs due to incompatibility in the process of fertilization which occurs in the post-pollination phase caused by pollen-tube was unable to penetrate the stigma, pollen-tube was unable to pass through the entire stylus, pollen-tube was not successful in the process of fertilization, ovules do not develop, seeds do not have endosperm, seeds do not germinate, seeds were weak and die, seeds do not grow into perfect plants and plants do not flower [6]. The presence of pollen sterility and incompatibility between pollen-stigma was the cause of the low capsule formation in sweet potatoes [7]. In the open pollination method, seeds were obtained by planting selected clones in the same area and crossing occurs naturally with the help of wind and insects. The increase in genetic diversity in these methods was lower than in controlled crosses, besides it was inefficient for genetic studies because the source of pollen (male parent) was unknown [8].

Controlled crosses with many parents involved and performed reciprocally aimed at increasing heterosigosity in $F_{1}$. High genetic diversity has the possibility of obtaining new individuals in the $F_{1}$ population. The Level of incompatibility in sweet potatoes depend on each combination of crosses. So far, the level of incompatibility was calculated based on the percentage of capsules/fruitsets. But in reality the capsules that was formed not all capsule contain of seeds, the percentage of empty seeds from crosses was also very high and seeds that contain embryos do not necessarily grow into normal seedlings. Therefore determining the level of incompatibility in sweet potatoes based on the percentage of normal seedlings will be more accurate [9]. Therefore information on the level of compatibility combination of clones, as male, female and both becomes important in determining the crossing parents. The objective of this study was to determine the level of compatibility of each combination of sweet potato crosses based on the percentage of normal seedlings.

\section{MATERIALS AND METHODS}

\subsection{Study Site}

Controlled crossing of sweetpotato clones was carried out in the Kendalpayak Experimental Garden, from March - October 2015 at Kendalpayak Research Station, Malang, East Java, Indonesia. Kendalpayak Research Station lies at $8^{\circ} 2^{\prime} 56.4^{\prime \prime} \mathrm{LS} 112^{\circ} 37^{\prime} 30^{\prime \prime} \mathrm{BT}$ with an altitude of $445 \mathrm{~m}$ a.s.l. Furthermore, seed nurseries from the crossing were carried out in the Indonesian Legumes and Tuber Crops Research Institute (ILETRI) greenhouse in Malang, East Java, Indonesia.

\subsection{Planting Materials}

The materials used were high-yielding potential clones of 17 clones and 3 clones as testers. The agricultural equipment used in the study were: petridish, crossing equipment. Crosses were performed reciprocally between clones that have high yield potential. The clones which have high yield potential, the amount of dry matter having a 
rough $23.32-35.02 \%$, and the ability to flower is moderate to very fertile. The characteristics of the clones are as discribed in Tables 1 and 2.

The selection of the crossing parents in sweet potato, besides the desired character also needs to consider the flowering ability and the degre of incompatibility. The choice of many flowering parents will increase the opportunity to enhance the number of crosses and the success of capsules and seed formation.

Each clone was planted in a plot measuring $1 \mathrm{~m}$ x $5 \mathrm{~m}$ with a spacing between $1 \mathrm{~m}$ ridges, a spacing between plants $25 \mathrm{~cm}$ and a spacing between ridges $30 \mathrm{~cm}$, each plot consisted of 20 plants.Controlled crosses used the Basuki method [10] as follows: crosses were performed without emasculation (the crossed clones were known self-incompatible). Method of crossing: flower buds that would bloom the next day were first tied using a string or thread. This method was to avoid contamination of other pollen by insects and wind. Binding of flowers was done around 13:00 till finished by which the flower started to open for the next day at around 06:00 10:00 for flowers to open maximum and to make easier for us carrying out a crosses.

The steps of crossing sweet potato cloneswere as follows: (a). flowers to be made as male parents were picked and placed in plastic boxes. (b). female parent to be crossed were labeled using a color thread (the color of the thread matches the male parent to be crossed). (c). Then the staples of the male parent flower were opened. (d). pollen was taken using tweezers. (d). the ends of the female parent flowers were also untied. (e). pollen was then sprinkled onthe surface of the stigma of the female parent. (f). the pollinated stigma was covered again with the flower crown and tied back with thread.

\subsection{Sample Collection}

Harvesting was done when the capsule/fruitsetwas dry and brown but has not broken. The harvested capsuleswere put in a labeled envelope. Furthermore, the capsuleswere dried under the sun rise for about three days. The dried capsuleswere then stored in a paper bag, labeled with a cross code and placed in the seed storage room. Observations made at this cross include:

a). The number of flowers that was crossedand the number of fruitsets formed; b). Percentage of fruitset, i.e. the number of fruitsets formed at each cross combination based on Indriani [9].

$\%$ of fruit set $=(\mathrm{Nf} / \Sigma \mathrm{Npf}) \times 100 \%$

Where: $\mathrm{Nf}=$ number of fruitsets; $\Sigma \mathrm{Npf}=$ total numbers of pollinated flowers

c). The average number of seeds per fruitset produced by each cross combination.

Average number of seeds $=\mathrm{Ns} / \mathrm{Nf}$

Where: $\mathrm{Ns}=$ number of seed; $\mathrm{Nf}=$ number of fruitsets.

The calculation was done after the seeds were cut off the hilum tip, if the tip of the radicles appeared, it mean that there was an embryo. While seeds that do not contain embryos will look empty. Each cross combination was counted by the number of seeds containing the embryo and the empty ones.

\section{d). Percentage of normal seedlings}

The seeds containing embryos were then planted on polybags with a diameter of $3 \mathrm{~cm}$, the percentage of germination was calculated on the seventh day with the following formula:

$\%$ of normal seedlings $=(\mathrm{Nns} / \Sigma \mathrm{Nst}) \times 100 \%$

Where: Nns = number of normal seedlings; $\Sigma$ Nst $=$ total number of seeds tested.

\subsection{Data Analysis}

Determination of the incompatibility level based on the percentage of normal seedlingswas as follows: compatible if the normal seedlings account for more than $20 \%$, partially compatible if the normal seedlings account betwen $10-20 \%$, very incompatible if the normal seedlings account less than $10 \%$, fully incompatible $0 \%$, if no normal seedlings is produced [9].

\section{RESULTS AND DISCUSSION}

Compatibility level based on \% normal seedlings of each crossing parents and its reciprocity with clone is shown in Table 3. Crosses amongs 17 clones with high yielding potential and 3 tester clones, resulted as many as 5,545 crosses, 1,296 formed capsules or fruit sets $(23.4 \%)$, 1956 seeds (35.3\%), 1,101 embryo-shaped 
seeds (19.9\%) and 530 growth to normal seedlings $(9.6 \%)$. The total number of crosses and the percentage of success in obtaining new clones was $9.6 \%$ Table 3.

The low percentage of normal seedlings produced was caused by many factors that influence. Physically, reproduction in sweetpotato is blocked because of several things including: flowering in sweetpotato is influenced by photoperiodisme, the receptive period is quite short and there is incompatibility [11]. Flower production is genetically controlled and influenced by the environment, several techniques used to stimulate flowering include temperature, photoperiodisme, manipulation of nutrition and the use of hormones [12].

The failure to produce new clones caused a sterility before pollination. The presence of sterile pollen can disturb the meiosis, while incompatibility during pollination causes pollen tubes to be unable to penetrate the stigma, ovules do not develop and the formation of seed structures is imperfect. Incompatibility during the pollination process until fertilization results in seed without embryos (empty seed). This causes the normal seedlings produced very low [6]. Therefore, information on the combination of compatible clones, as male, female and both becomes important in determining the crossing parents. The level of incompatibility depends on each combination of crosses.

\subsection{Number of Crosses}

The crosses number of 17 high yielding Clones with three Testers of each crossing parents
(Clone as female $\mathrm{x}$ Tester as male) and its reciprocal (Clone as male $x$ Tester as female) is presented in Table 4. When Clone used as female, themean of crosses number of 17 clones with Tester 1 , Tester 2 , and Tester 3 were $71.5,71.0$, and 71.8, respectively, which was not diffrence among Testers. However, when Clone used as male, the mean of crosses number of 17 clones with Tester 1 , Tester 2 , and Tester 3 were 24.5, 31.8, and 48.8, respectively which was diffrence among Testers Table 4 and Fig. 1.

\subsection{Number of Normal Seedling}

The number of normal seedling derived from crosses of 17 high yielding potential clones with three testers of each crossing parents (Clone as female $x$ Tester as male) and its reciprocal (Clone as male $\mathrm{x}$ Tester as female) is presented in Table 5. When Clone used as female, the mean of normal seedling derived from crosses of 17 clones with Tester 1, Tester 2, and Tester 3 were 17.92, 41.81, and 27.81, respectively, which was diffrence among Testers. However, when Clone used as male, the mean of normal seedling derived from crosses of 17 clones with Tester 1, Tester 2, and Tester 3 were 0 , 18.5, and 28.86, respectively which was diffrence among Testers Table 5 and Fig. 2. Clone C-141 gave the higest of number of normal seedling among 17 clones of $51.7,58.2$, and 43.9 with Tester 1, Tester 2, and Tester 3, respectively. However, when Clone used as male or reciprocal crosses, the mean of crosses number of 17 clones with Tester 1 , Tester 2, and Tester 3 were $0,76.5$, and 33.3 , respectively Table 5 .

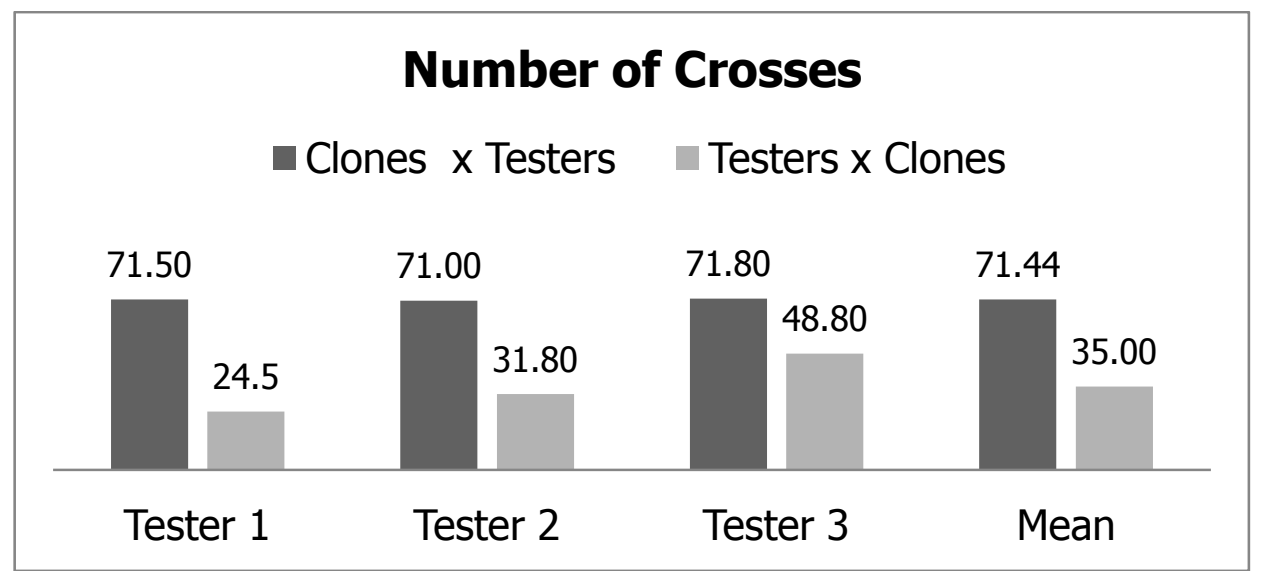

Fig. 1. Crosses number average of $\mathbf{1 7}$ high yielding potential clones with three testers of each crossing parents (Clones $x$ Testers ${ }^{1)}$ ) and its reciprocal (Testers $\left.{ }^{1}\right) \mathrm{x}$ Clones )

${ }^{1)}$ Tester 1 = C-001 (Cangkuang); Tester 2 = C-011; and Tester $3=$ C-127 
Table 1. List of the characteristics of sweet potato clones with high yield potential

\begin{tabular}{|c|c|c|c|c|c|c|c|}
\hline \multirow[t]{2}{*}{ No. } & \multirow[t]{2}{*}{ Clone code } & \multirow[t]{2}{*}{ Clone Name } & \multirow[t]{2}{*}{ Yield Potential (ton/ha) } & \multirow[t]{2}{*}{ Dry matter (\%) } & \multirow[t]{2}{*}{ Flowering ability } & \multicolumn{2}{|c|}{ Tuber Color ${ }^{1)}$} \\
\hline & & & & & & Skin & Flesh \\
\hline 1 & C-139 & MSU 07023-86 & 50.83 & 23.32 & high & R5 & $\mathrm{O} 4$ \\
\hline 2 & C-053 & UJ-35 Batatas Merah & 48.85 & 25.41 & high & Y5 & Y4O1 \\
\hline 3 & C-083 & MSU 07031-28 & 45.11 & 24.08 & low & $\mathrm{R} 2$ & $\mathrm{O} 3$ \\
\hline 4 & C-145 & MSU 07022-15 & 42.92 & 26.65 & intermediate & Y3 & Y3 \\
\hline 5 & C-125 & MSU 07022-12 & 37.02 & 30.34 & high & Y2 & Y2 \\
\hline 6 & C-141 & MSU 07015-54 & 30.03 & 33.90 & very high & $\mathrm{R} 4$ & W \\
\hline 7 & C-062 & MSU 10039-03 & 39.96 & 31.07 & high & Y2 & $\mathrm{Y} 1$ \\
\hline 8 & C-039 & UJ-16 Slape & 36.34 & 25.79 & high & O1 & O4 \\
\hline 9 & C-007 & Papua Solossa & 31.94 & 34.25 & very high & Y3 & Y3 \\
\hline 10 & C-004 & Kidal & 31.58 & 35.02 & high & $\mathrm{R} 4$ & Y4 \\
\hline 11 & C-026 & Cilembu-1 & 30.64 & 30.38 & intermediate & Y4 & Y3O3 \\
\hline 12 & C-016 & IR Melati & 33.80 & 24.19 & intermediate & $\mathrm{R} 4$ & $\mathrm{Y} 1$ \\
\hline 13 & C-117 & RWAS 10062-01 & 32.45 & 29.70 & high & P5 & P5 \\
\hline 14 & C-065 & MSU 10048-09 & 33.17 & 26.81 & high & Y2 & $W$ \\
\hline 15 & C-131 & MSU 07012-06 & 36.29 & 25.38 & high & $\mathrm{R} 4$ & $\mathrm{O} 3$ \\
\hline 16 & C-090 & MSU 09008-92 & 37.54 & 29.77 & high & $\mathrm{R} 6$ & P5 \\
\hline 17 & C-123 & MSU 07009-75 & 32.18 & 32.98 & high & $\mathrm{R} 4$ & Y2 \\
\hline
\end{tabular}

Color intensity consists of: 7 = very dark, $6=$ dark, $5=$ slightly dark, $4=$ bright, $3=$ pale, $2=$ slightly pale and $1=$ very pale

Table 2. List of the characteristics of sweet potato clones used as testers

\begin{tabular}{|c|c|c|c|c|c|c|c|}
\hline \multirow[t]{2}{*}{ Tester } & \multirow[t]{2}{*}{ Clone code } & \multirow[t]{2}{*}{ Clone Name } & \multirow[t]{2}{*}{ Yield Potential (ton/ha) } & \multirow[t]{2}{*}{ Dry matter (\%) } & \multirow[t]{2}{*}{ Flowering ability } & \multicolumn{2}{|c|}{ Tuber Color ${ }^{T)}$} \\
\hline & & & & & & Skin & Flesh \\
\hline $\mathrm{T} 1$ & C-001 & Cangkuang & 30.00 & 35.2 & high & R4 & Y2 \\
\hline T2 & C-011 & Beta-2 & 36.81 & 23.7 & high & $\mathrm{R} 6$ & $\mathrm{O} 3$ \\
\hline T3 & C-127 & RIS 10068-02 & 38.86 & 31.1 & high & Y5 & Y3O3 \\
\hline
\end{tabular}

Color intensity consists of: $7=$ very dark, $6=$ dark, $5=$ slightly dark, $4=$ bright, $3=$ pale, $2=$ slightly pale and $1=$ very pale 
Table 3. Number of fruit set, seed, and normal seedling obtained from crosses of 17 high yielding potential clones with three testers

\begin{tabular}{|c|c|c|c|c|c|}
\hline & Crosses & Fruit set & Total Seed & Filled seed & Normal seedlings \\
\hline Number & 5,545 & 1,296 & 1,956 & 1,101 & 530 \\
\hline Percentage (\%) & 100.0 & 23.4 & 35.3 & 19.9 & 9.6 \\
\hline
\end{tabular}

Table 4. Crosses number of 17 high yielding potential clones with three testers of each crossing parents and its reciprocal

\begin{tabular}{|c|c|c|c|c|c|c|c|c|c|}
\hline \multirow[t]{3}{*}{ No. } & \multirow[t]{3}{*}{ Clone code } & \multicolumn{8}{|c|}{ Number of crosses } \\
\hline & & \multicolumn{4}{|c|}{ Clone $\times$ Tester ${ }^{I I}$} & \multicolumn{4}{|c|}{ Reciprocal (Tester x Clone) ${ }^{11}$} \\
\hline & & Tester $1^{2)}$ & 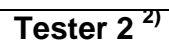 & 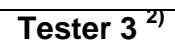 & Mean & Tester $1^{2)}$ & 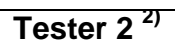 & Tester $3^{21}$ & Mean \\
\hline 1 & C-139 & 164 & 134 & 97 & 131.67 & 17 & 54 & 61 & 44.0 \\
\hline 2 & C-053 & 78 & 74 & 55 & 69.00 & 7 & 23 & 46 & 25.3 \\
\hline 3 & C-083 & 25 & 16 & 32 & 24.33 & 41 & 31 & 59 & 43.7 \\
\hline 4 & C-145 & 79 & 72 & 74 & 75.00 & 15 & 34 & 68 & 39.0 \\
\hline 5 & C-125 & 79 & 48 & 52 & 59.67 & 61 & 76 & 73 & 70.0 \\
\hline 6 & C-141 & 146 & 145 & 219 & 170.00 & 38 & 37 & 26 & 33.7 \\
\hline 7 & C-062 & 34 & 61 & 68 & 54.33 & 16 & 8 & 51 & 25.0 \\
\hline 8 & C-039 & 82 & 123 & 174 & 126.33 & 21 & 72 & 96 & 63.0 \\
\hline 9 & C-007 & 74 & 51 & 91 & 72.00 & 15 & 31 & 48 & 31.3 \\
\hline 10 & C-004 & 73 & 43 & 35 & 50.33 & 35 & 65 & 57 & 52.3 \\
\hline 11 & C-026 & 102 & 117 & 92 & 103.67 & 58 & 31 & 67 & 52.0 \\
\hline 12 & C-016 & 65 & 68 & 79 & 70.67 & 11 & 4 & 39 & 18.0 \\
\hline 13 & C-117 & 61 & 59 & 62 & 60.67 & 56 & 16 & 43 & 38.3 \\
\hline 14 & C-065 & 45 & 51 & 58 & 51.33 & 8 & 28 & 46 & 27.3 \\
\hline 15 & C-131 & 50 & 50 & 65 & 55.00 & 18 & 20 & 15 & 17.7 \\
\hline 16 & C-090 & 13 & 50 & 25 & 29.33 & 0 & 0 & 22 & 7.3 \\
\hline 17 & C-123 & 46 & 45 & 11 & 34.00 & 0 & 10 & 59 & 23.0 \\
\hline Mean & & 71.5 & 71.0 & 71.8 & 71.44 & 24.5 & 31.8 & 48.8 & 35.0 \\
\hline
\end{tabular}

${ }^{1}$ Clone $\times$ Tester = Clone (as Female) $\times$ Tester (as Male); ${ }^{17}$ Reciprocal $=$ Tester (as Female) $\times$ Clone (as Male). ${ }^{2}$ Tester $1=$ C-001 (Cangkuang); Tester $2=$ C-011; and Tester $3=$ C-127 


\subsection{Level of Cross Compatibility}

The level of cross compatibility derived from crosses of 17 high yielding potential clones with three testers of each crossing parents (Clone as female $x$ Tester as male) and its reciprocal (Clone as male $\mathrm{x}$ Tester as female) is presented in Table 6. When Clone used as female, the mean of normal seedling derived from crosses of 17 clones with three Testers, namely Tester 1 , Tester 2, and Tester 3 were 6, 13, and 9, respectively, which was diffrence among Testers. However, when Clone used as male, the mean of normal seedling derived from crosses of 17 clones with three Testers, namely Tester 1 , Tester 2 , and Tester 3 were 0,6 , and 9 , respectively which was diffrence among Testers Table 5 and Fig. 3. Three clones ( C141, C-007, and C-131) gave the best level of cross compatibility of when crossed to three Testers (Tester 1, Tester 2, and Tester 3). However, when Clone used as male or reciprocal crosses, the mean of crosses number of 17 clones with three Testers, the level of cross compatibility only with Tester 2 and Tester 3 Table 6. These data suggested that the rule of clone used as female or male determined the the level of cross compatibility of crosses derived from crosses or there was a reciprocal difference in the number of the level of cross compatibility of sweet potato.

\subsection{The Success Rate of Hand Pollination}

The reciprocal crossing between 17 clonesof high yield potential and Tester1 (C-001=
Cangkuang Variety) performed 1,633 crosses forming $15.3 \%$ capsules. Normal plants produced as much as $2.6 \%$. Whereas the same clones crossed with Beta-2 varieties (C-011) performed 1,747 crosses produce 432 fertile capsules $(24.7 \%)$ and normal seedlings that could be produced were 200 clones (11.4\%). Whereas crosses with the number of $\mathrm{C}-127$ as tester (Tester 3) were 2,165 times, able to form capsules as much as $28.4 \%$ and normal plants $288(13.3 \%)$. The level of success in obtaining new clones were different among the parents. The number of crosses made was between 2191,321 times. Each clone as female and male parents performed a number of 0 - 142 new clones Table 7.

The success of crossing each clone of all crosses performed, both male and female is listed in Table 7. Three clones used as testers have the ability to flower. Controlled crosses between Testers and 17 high yielding potential clones carried out with the reciprocal, have different success rates for crosses as shown in Table 7. Success of crosses based on percentage of capsules is between $13.2-40.3 \%$. Whereas based on the percentage of normal seedlings, it shows the target $0-18.0 \%$. In the test clones, it turns out that clone No. 1 is unable to produce normal plants when used as females. Clone $\mathrm{C}-001$ and $\mathrm{C}-127$ are more suitable as male parents. Clone 11 can be used as male and female parents. The success rate of crossing as male and female parents of both clones in producing normal seedlings is relatively balanced.

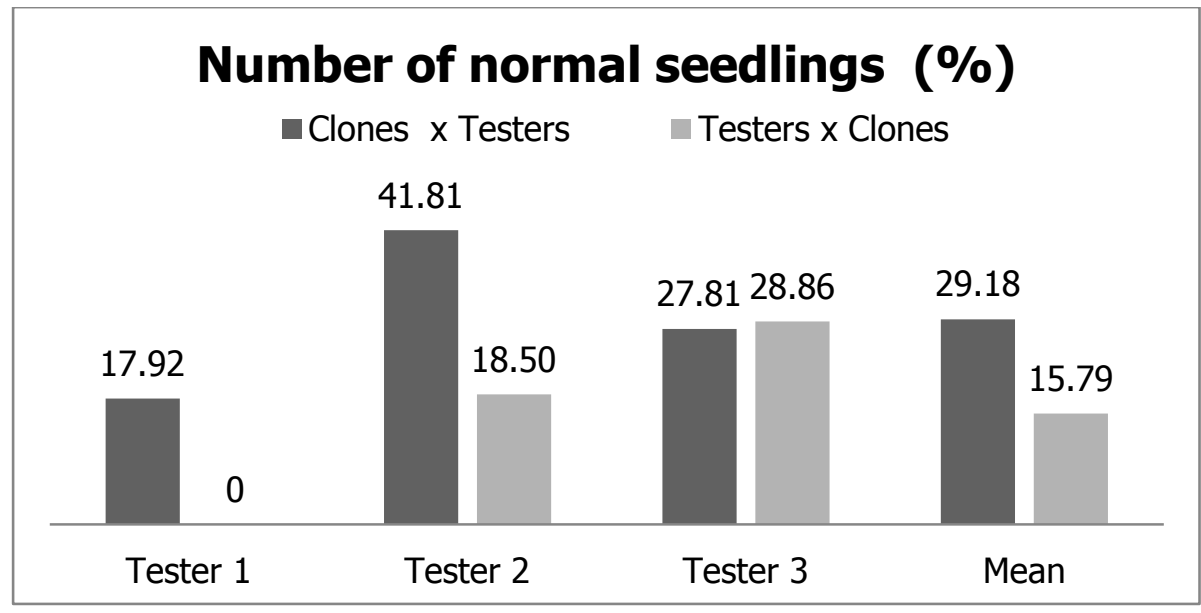

Fig. 2. Number of normal seedling average of crosses of 17 high yielding potential clones with three testers of each crossing parents (Clones $x$ Testers) and its reciprocal (Testers $x$ Clones )

1) Tester $1=$ C-001 (Cangkuang); Tester $2=C-011$; and Tester $3=C-127$ 
Table 5. Number of normal seedling derived from crossing of 17 high yielding potential clones with three testers of each crossing parents and its reciprocal

\begin{tabular}{|c|c|c|c|c|c|c|c|c|c|}
\hline \multirow[t]{3}{*}{ No. } & \multirow[t]{3}{*}{ Clone code } & \multicolumn{8}{|c|}{ Number of normal seedlings (\%) } \\
\hline & & \multicolumn{4}{|c|}{ Clone $\times$ Tester $^{11}$} & \multicolumn{4}{|c|}{ Reciprocal (Tester x Clone) $^{T \prime}$} \\
\hline & & Tester $1^{2)}$ & Tester $2^{2)}$ & Tester $3^{2)}$ & Mean & Tester $1^{21}$ & 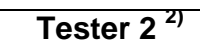 & Tester $3^{21}$ & Mean \\
\hline 1 & C-139 & 18.8 & 0 & 8.3 & 9.03 & 0 & 0 & 61.3 & 20.43 \\
\hline 2 & C-053 & 0 & 57.7 & 21.4 & 2637 & 0 & 0 & 56.0 & 18.67 \\
\hline 3 & C-083 & 0 & 36.4 & 52.9 & 29.77 & 0 & 0 & 51.5 & 17.17 \\
\hline 4 & C-145 & 0 & 0 & 50.0 & 16.67 & 0 & 17.6 & 43.6 & 20.40 \\
\hline 5 & C-125 & 0 & 30.8 & 0 & 10.27 & 0 & 55.6 & 0 & 18.53 \\
\hline 6 & C-141 & 51.7 & 58.2 & 43.9 & 51.27 & 0 & 76.5 & 33.3 & 36.60 \\
\hline 7 & C-062 & 0 & 27.3 & 17.6 & 14.97 & 0 & 0 & 0 & 0.00 \\
\hline 8 & C-039 & 0 & 57.1 & 23.5 & 26.87 & 0 & 31.3 & 54.3 & 28.53 \\
\hline 9 & C-007 & 43.8 & 85.7 & 55.6 & 61.70 & 0 & 25.0 & 36.8 & 20.60 \\
\hline 10 & C-004 & 28.6 & 72.7 & 10.0 & 37.10 & 0 & 12.5 & 17.9 & 10.13 \\
\hline 11 & C-026 & 0 & 68.0 & 62.9 & 43.63 & 0 & 0 & 71.1 & 23.70 \\
\hline 12 & C-016 & 0 & 38.5 & 0 & 12.83 & 0 & 0 & 0 & 0.00 \\
\hline 13 & C-117 & 41.7 & 0 & 61.1 & 34.27 & 0 & 0 & 0 & 0.00 \\
\hline 14 & C-065 & 0 & 38.5 & $15, .6$ & 18.03 & 0 & 64.7 & 64.9 & 43.20 \\
\hline 15 & C-131 & 100 & 58.3 & 50.0 & 69.43 & 0 & 31.3 & 0 & 10.43 \\
\hline 16 & C-090 & 0 & 0 & 0 & 0.00 & 0 & 0 & 0 & 0.00 \\
\hline 17 & C-123 & 20 & 81.5 & 0 & 33.83 & 0 & 0 & 0 & 0.00 \\
\hline Mean & & 17.92 & 41.81 & 27.81 & 29.18 & 0 & 18.5 & 28.86 & 15.79 \\
\hline
\end{tabular}


Table 6. Level of compatibility base on normal seedling derived from crossing of $\mathbf{1 7}$ high yielding potential clones with three testers of each crossing parents and its reciprocity

\begin{tabular}{|c|c|c|c|c|c|c|c|c|c|}
\hline \multirow[t]{3}{*}{ No. } & \multirow[t]{3}{*}{ Clone code } & \multicolumn{8}{|c|}{ Level of Compatibility $^{1)}$} \\
\hline & & \multicolumn{4}{|c|}{ Clone $\times$ Tester $^{2)}$} & \multicolumn{4}{|c|}{ Reciprocal (Tester x Clone) ${ }^{2)}$} \\
\hline & & Tester $1^{3)}$ & Tester $2^{3)}$ & Tester $3^{3)}$ & $\begin{array}{c}\text { Number of } \\
\text { compa-tible }^{4)}\end{array}$ & Tester $1^{3)}$ & Tester $2^{3)}$ & Tester $3^{3)}$ & $\begin{array}{c}\text { Number of } \\
\text { compa-tible }\end{array}$ \\
\hline 1 & C-139 & PC & $\mathrm{FI}$ & $\mathrm{VI}$ & 0 & $\mathrm{FI}$ & $\mathrm{FI}$ & $\mathrm{C}$ & 1 \\
\hline 2 & C-053 & $\mathrm{FI}$ & C & C & 2 & $\mathrm{FI}$ & $\mathrm{FI}$ & C & 1 \\
\hline 3 & C-083 & $\mathrm{FI}$ & C & $\mathrm{C}$ & 2 & $\mathrm{FI}$ & $\mathrm{FI}$ & C & 1 \\
\hline 4 & C-145 & $\mathrm{FI}$ & $\mathrm{FI}$ & $\mathrm{C}$ & 1 & $\mathrm{FI}$ & PC & C & 1 \\
\hline 5 & C-125 & $\mathrm{FI}$ & C & $\mathrm{FI}$ & 1 & $\mathrm{FI}$ & C & $\mathrm{FI}$ & 1 \\
\hline 6 & C-141 & $C$ & $C$ & $C$ & 3 & $\mathrm{FI}$ & $C$ & $C$ & 2 \\
\hline 7 & C-062 & $\mathrm{FI}$ & $C$ & $P C$ & 1 & $\mathrm{FI}$ & $\mathrm{FI}$ & $\mathrm{FI}$ & 0 \\
\hline 8 & C-039 & $\mathrm{FI}$ & C & C & 2 & $\mathrm{FI}$ & $C$ & $C$ & 2 \\
\hline 9 & C-007 & C & $C$ & $C$ & 3 & $\mathrm{FI}$ & $C$ & $C$ & 2 \\
\hline 10 & C-004 & $C$ & $C$ & PC & 2 & $\mathrm{FI}$ & PI & PC & 0 \\
\hline 11 & C-026 & $\mathrm{FI}$ & C & C & 2 & $\mathrm{FI}$ & $\mathrm{FI}$ & $C$ & 1 \\
\hline 12 & C-016 & $\mathrm{FI}$ & $C$ & $\mathrm{FI}$ & 1 & $\mathrm{FI}$ & $\mathrm{FI}$ & $\mathrm{FI}$ & 0 \\
\hline 13 & C-117 & $C$ & $\mathrm{FI}$ & $C$ & 2 & $\mathrm{FI}$ & $\mathrm{FI}$ & $\mathrm{FI}$ & 0 \\
\hline 14 & C-065 & $\mathrm{FI}$ & $C$ & PC & 1 & $\mathrm{FI}$ & $C$ & $C$ & 2 \\
\hline 15 & C-131 & C & $C$ & $C$ & 3 & $\mathrm{FI}$ & C & $\mathrm{FI}$ & 1 \\
\hline 16 & C-090 & $\mathrm{FI}$ & $\mathrm{FI}$ & $\mathrm{FI}$ & 0 & 0 & 0 & $\mathrm{FI}$ & 0 \\
\hline 17 & C-123 & $C$ & C & $\mathrm{FI}$ & 2 & 0 & $\mathrm{FI}$ & $\mathrm{FI}$ & 0 \\
\hline \multicolumn{2}{|c|}{$\begin{array}{l}\text { Total number of } \\
\text { compatible }\end{array}$} & 6 & 13 & 9 & 28 & 0 & 6 & 9 & 15 \\
\hline
\end{tabular}




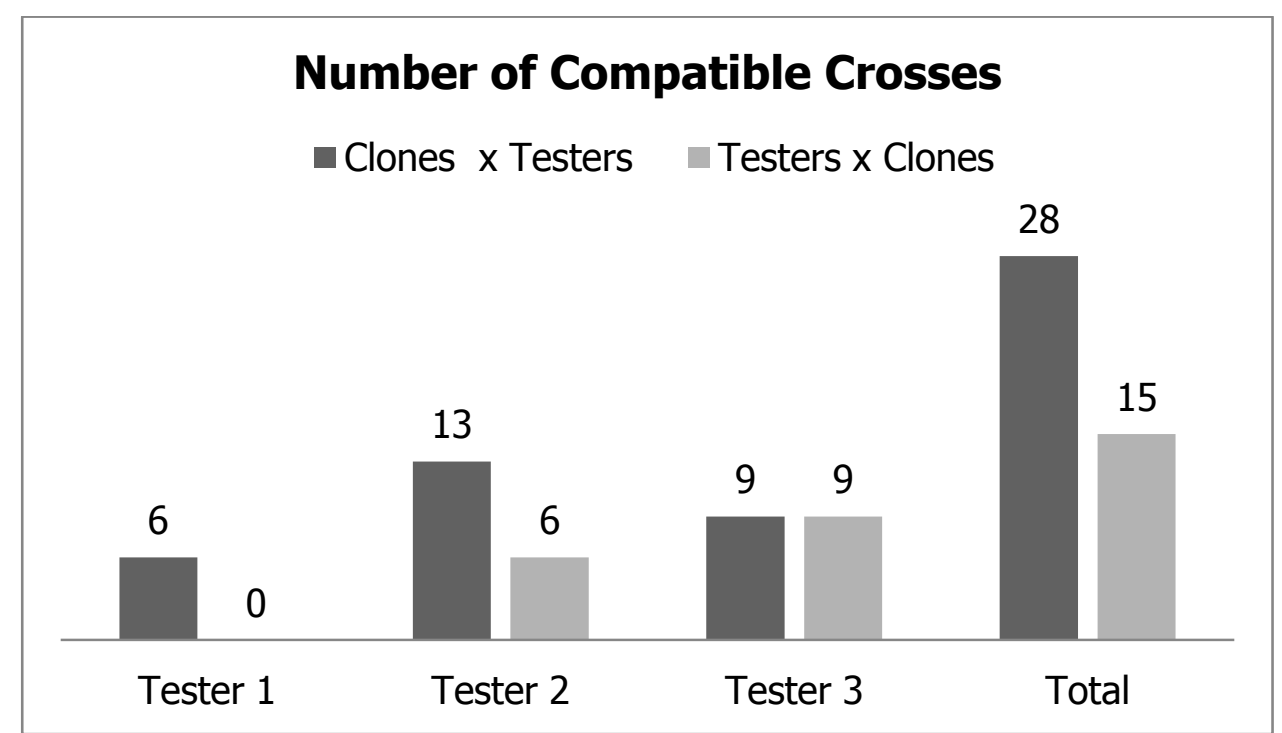

Fig. 3. Number of compatible level of crosses average of crosses of $17 \mathrm{high}$ yielding potential clones with three testers of each crossing parents (Clones $x$ Testers ${ }^{1)}$ ) and its reciprocal (Testers ${ }^{1)} \times$ Clones )

1) Tester $1=C-001$ (Cangkuang); Tester $2=C-011$; and Tester $3=C-127$

Based on the percentage of normal seedlings produced, the highest success was clone $\mathrm{C}-123$ as females that was $18 \%$. However, cloneC-123 as males showed $0 \%$ of success (not suitable as males). The ability to produce normal seedlings that reach $\geq 10 \%$ as a male include clone $\mathrm{C}-145$, C-039, C-026 and C-065; while as a female include: clone C-141, C-007, C-026, C-131 and C-123 Table 8. Clone C-007 (Papua Solossa) was more suitable as a female parent with a compatibility level of $87.5 \%$ and a successful crossing of $13.7 \%$. This may be caused by a high level of stigma receptivity pollen. Susanto et al. [13] reported that the stigma receptivity of the Papua Solossa variety showed $100 \%$, which means that the clone was more suitable as a female.

Pollen sterility and the incompatibility of pollenstigma interactions also play a role in causing low capsules formation [7]. Even in full incompatible combinations cannot produce embryonic-shaped seeds that can grow into normal plants. The compatibility of a cross is determined by two criteria, namely the failure or success of pollen germination in style and the success or failure of fertilization after pollination [14].

Low percentage of normal seedlings produced was due to many factors that influence. Physiologically, reproduction is blocked due to flowering in sweetpotato is influenced by photoperiodism, the receptive period is quite short and there is incompatibility [11]. Flower production is genetically controlled and influenced by environment, several techniques used to stimulate flowering include temperature, photoperiodism, manipulation of nutrition and the use of hormones [12].

Capsules of the physiologis cross-ripening about one month after crossing. Characteristics of capsules that are ready to be harvested are marked by the color of the capsules which is brown/black and dry, before breaking it must be harvested immediately. Capsules usually have 13 seeds depending on the combination of the crosses and the degree of incompatibility. Seed coat is very hard, its viability can last for a long time. At $50 \%$ humidity and a temperature of 18 ${ }^{\circ} \mathrm{C}$, viability can be maintained for 20 years [15]. Seed weight of 1.3 - $3.0 \mathrm{~g}$ per 100 seeds depends on a combination of crosses [16]. Hard sweet potato seed skin requires special treatment for the break of its dormitory, using the hilum cutting method [17].

The embryonic and empty seeds will be seen after hilum cutting, then the viability of the embryonic seeds were tested. The success of fertilization can be seen from the capsules formed, in a compatible crossbreed combination, generally capsules with 1 or 2 seeds sometimes have 3 seeds. Gruneberg et al.[1] states that in controlled crosses can be obtained 1-3 seeds per 
Table 7. Percentage of successful crosses of high yielding potential clones with three clone testers

\begin{tabular}{|c|c|c|c|c|c|c|c|c|c|}
\hline No. & $\begin{array}{l}\text { Clones } \\
\text { code }\end{array}$ & Parent as & $\begin{array}{l}\text { Number of } \\
\text { crosses }\end{array}$ & $\begin{array}{l}\text { Number of } \\
\text { capsules }\end{array}$ & Fertile capsules (\%) & $\begin{array}{l}\text { Number of } \\
\text { seeds }\end{array}$ & $\begin{array}{l}\text { Number of } \\
\text { fertiled seeds }\end{array}$ & $\begin{array}{l}\text { New } \\
\text { clones }\end{array}$ & $\begin{array}{l}\text { Success of } \\
\text { crosses (\%) }\end{array}$ \\
\hline \multirow[t]{2}{*}{1} & C-139 & Female & 1,068 & 148 & 13.9 & 179 & 121 & 25 & 2.3 \\
\hline & & Male & 509 & 157 & 30.8 & 210 & 145 & 44 & 8.6 \\
\hline \multirow[t]{2}{*}{2} & C-053 & Female & 532 & 129 & 24.2 & 166 & 94 & 36 & 6.7 \\
\hline & & Male & 404 & 133 & 32.9 & 158 & 50 & 28 & 6.9 \\
\hline \multirow[t]{2}{*}{3} & C-083 & Female & 278 & 112 & 40.3 & 151 & 62 & 19 & 6.8 \\
\hline & & Male & 364 & 86 & 23.6 & 112 & 33 & 17 & 4.7 \\
\hline \multirow[t]{2}{*}{4} & C-145 & Female & 556 & 49 & 8.8 & 55 & 20 & 7 & 1.3 \\
\hline & & Male & 411 & 160 & 38.9 & 251 & 144 & 56 & 13.6 \\
\hline \multirow[t]{2}{*}{5} & C-125 & Female & 456 & 70 & 15.4 & 91 & 34 & 8 & 1.8 \\
\hline & & Male & 572 & 88 & 15.4 & 109 & 64 & 30 & 5.2 \\
\hline \multirow[t]{2}{*}{6} & C-141 & Female & 1,321 & 320 & 24.2 & 486 & 292 & 142 & 10.7 \\
\hline & & Male & 421 & 209 & 49.6 & 355 & 107 & 42 & 9.9 \\
\hline \multirow[t]{2}{*}{7} & C-062 & Female & 449 & 50 & 11.1 & 86 & 56 & 19 & 4.2 \\
\hline & & Male & 408 & 110 & 26.9 & 145 & 49 & 11 & 2.7 \\
\hline \multirow[t]{2}{*}{8} & C-039 & Female & 996 & 93 & 9.3 & 94 & 44 & 23 & 2.3 \\
\hline & & Male & 565 & 194 & 34.3 & 298 & 210 & 89 & 15.8 \\
\hline \multirow[t]{2}{*}{9} & C-007 & Female & 593 & 196 & 33.1 & 332 & 146 & 81 & 13.7 \\
\hline & & Male & 374 & 120 & 32.1 & 166 & 48 & 20 & 5.3 \\
\hline \multirow[t]{2}{*}{10} & C-004 & Female & 509 & 74 & 14.5 & 101 & 43 & 14 & 2.8 \\
\hline & & Male & 526 & 164 & 31.2 & 225 & 112 & 26 & 4.9 \\
\hline \multirow[t]{2}{*}{11} & C-026 & Female & 719 & 167 & 23.2 & 225 & 124 & 79 & 10.9 \\
\hline & & Male & 431 & 147 & 34.1 & 218 & 85 & 44 & 10.2 \\
\hline \multirow[t]{2}{*}{12} & C-016 & Female & 577 & 78 & 13.5 & 110 & 42 & 25 & 4.3 \\
\hline & & Male & 303 & 35 & 11.6 & 29 & 8 & 6 & 1.9 \\
\hline \multirow[t]{2}{*}{13} & C-117 & Female & 499 & 104 & 20.8 & 130 & 97 & 43 & 8.6 \\
\hline & & Male & 413 & 93 & 22.5 & 111 & 38 & 1 & 0.2 \\
\hline \multirow[t]{2}{*}{14} & C-065 & Female & 445 & 86 & 19.3 & 130 & 63 & 15 & 3.4 \\
\hline & & Male & 279 & 95 & 34.0 & 145 & 72 & 40 & 14.3 \\
\hline 15 & C-131 & Female & 460 & 121 & 26.3 & 154 & 136 & 77 & 16.7 \\
\hline
\end{tabular}


Indriani et al.; ARRB, 36(5): 23-37, 2021; Article no.ARRB.68071

\begin{tabular}{|c|c|c|c|c|c|c|c|c|c|}
\hline No. & $\begin{array}{l}\text { Clones } \\
\text { code }\end{array}$ & Parent as & $\begin{array}{l}\text { Number of } \\
\text { crosses }\end{array}$ & $\begin{array}{l}\text { Number of } \\
\text { capsules }\end{array}$ & Fertile capsules (\%) & $\begin{array}{l}\text { Number of } \\
\text { seeds }\end{array}$ & $\begin{array}{l}\text { Number of } \\
\text { fertiled seeds }\end{array}$ & $\begin{array}{l}\text { New } \\
\text { clones }\end{array}$ & $\begin{array}{l}\text { Success of } \\
\text { crosses (\%) }\end{array}$ \\
\hline & & Male & 376 & 172 & 45.7 & 228 & 88 & 16 & 4.3 \\
\hline \multirow[t]{2}{*}{16} & C-090 & Female & 252 & 39 & 15.5 & 41 & 27 & 12 & 4.8 \\
\hline & & Male & 219 & 57 & 26.0 & 69 & 24 & 5 & 2.3 \\
\hline \multirow[t]{2}{*}{17} & C-123 & Female & 311 & 101 & 32.5 & 127 & 94 & 56 & 18.0 \\
\hline & & Male & 260 & 5 & 1.9 & 6 & 0 & 0 & 0 \\
\hline
\end{tabular}


capsules. The results showed a high percentage of empty seeds, and the number of embryonic seeds did not grow into normal plants.

Cross incompatibility can occur on the surface of stigma due to incompatible between the pollen substance and the exudate on the stigma. Whereas sterility can be caused by pollen tube failure from stigma to penetrate the force toward the ovary [18]. Sterility in autopolyploid plants causes chromosomal dual distribution to meiosis not normal [19]. Sterility, incompatibility and environmental factors affect various stages of the reproductive process. These factors cause germination and seed vigor to be low, abnormal plant types, reduced flowering, ovul and embryo abortion and low seed formation [15]. The low number of seeds formed causes the percentage of normal plants produced is also low. This can cause failure in fertilization, according to [16], there are two causes, namely pollen germination, but fertilization fails and the embryo grows weak and even dies after fertilization.

Evaluation of the level of incompatibility of each cross combination is needed to obtain information on the suitability of each clone as male, female and both. High compatibility between the parents is expected to form normal capsules, seeds and seedlings that have the desired characteristics. According to Martin[6], differences in the incompatibility level of each combination may cause failure in the following stages: the stage before pollination due to male and female gametes are not normal. Pollination stage is generally caused by pollen that does not germinate and stigma does not stimulate germination. The stage after pollination often results in the pollen tube being unable to penetrate the stigma and pistil stems so that it does not reach the ovule. Other factorsaffect include ovules that are not fully developed and abnormality of endosperm, resulting that the seeds do not germinate, seedlings grow weak, abnormal and even die.

Conventional sweet potato breeding through hybridization is an effective wayin obtaining superior sweet potato clones. The existence of self-incompatibility (self incompatible) and cross incompatible (cross incompatible) is an obstacle to hybridizationsweet potato [20]. Basically, incompatibility system in Convolvulaceae family (for example sweetpotato), Brassicaseae, and Compositae are sporophytic, meaning incompatibility is determined by the phenotype of the pollen not the gametes [21]. The factors affecting the failure of capsules/seed formation in controlled crosses also causes sterility after pollen germination. However, there is a failure in the formation of pollen tubes resulting that fertilization does not occur, embryo abortion occurs or seedlings grow abnormally/weakly [16]. Meanwhile, according to Martin [6] sterility occurs in the pre-pollination phase, due to the presence of sterile pollen (not viable) and in the postpollination phase that occurs during the fertilization/fertilization process. Theavailability of parents withcross-incompatibility cause to very low success of crosses [22]

The process of fruit and seed formations in a controlled cross-pollination is a complex mechanism because of the cross-incompatibility issue which appears in sweetpotato. Seed vigor produced depends on each combination cross compatibility. The quality of one seed lot was reflected on the seed vigor counted based on the on-site growth rate [23]. Incompatibility may occurs on the surface of stigma due to a mismatch between the pollen substance and the exudate on the stigma. Whereas sterility may cause pollen tube failure from stigma to penetrate the force toward the ovary [18]. Sterility in autopolyploid plants causes chromosomal dual distribution to meiosis not normal [19]. Sterility, incompatibility and environmental factors affect various stages of the reproductive process. These factors cause germination and seed vigor to be low, abnormal plant types, reduced flowering, ovul and embryo abortion and low seed formation [15]. The low number of seeds formed causes the percentage of normal plants produced is also low. Failure in fertilization are caused by pollen germination but fertilization fails and the embryo grows weak even dies after fertilization[16].

Fertilization of the embryo grows is very important in developing high yielding sweet potato variety since we need a cheap price of carbohydrat source for human consumption from the sweet potato tuber yield as well as for animal feed from sweet potato leaves. The possibility of converting sweet potato leaves to animal feed through fermentation is encouraging technology [24].

\section{CONCLUSION}

The Level of compatibility of each cross combination showed differences, by which each parent showed its suitability as male parent and female parent. Clone C-011 (Tester 2) was the 
most compatible as male parent, while clone C141, C-007 and C-131 were most compatible as female parents. Clone C-127 (Tester 3) was the most compatible as both male and female parents. Clone C-001 (Tester 1) could not be used as female parent due to high incompatibility. This compatible clone information is very useful in determining of both controlled crosses and open crosses in sweet potatoes in order to increase breeding efficiency.

\section{ACKNOWLEDGEMENT}

We would like to thank the the Director General of thelndonesian Agency for Research and Development (IAARD) in Jakarta, the Director of thelndonesian Food Crops Research and Development (ICFORD) in Bogor, the Head of the Indonesian Legumes and Tuber Crops Research Institute (ILETRI) in Malang who gave facilities for conducting this research. Thanks to all of supporting stafs that worked hard to make this research done.

\section{COMPETING INTERESTS}

Authors have declared that no competing interests exist.

\section{REFERENCES}

1. Gruneberg WJ, D. Ma, ROM EE, Cwerey $\mathrm{K}$, Huamani F, Diaz R, et al. Advances in Sweetpotato Breeding from 1992 to 2012. African Potato Association Conference in 2013. CAB International. 2015;69.

2. Nwashiyama I. Evolution and domestication of the sweet potato. Botanical Magazine.1971;84:377 - 387.

3. Nwashiyama I, Miyazaki T, Sakamoto S. Evolutionary autoploidy in the sweet potato [Ipomoea batatas (L.) Lam.] and its progenitors. Euphytica. 1975;24:197-208.

4. Kowyama Y, Tsuchiya T, Kakeda K. Sporophytic self-incompatibility in Ipomoea trifida, a close relative of sweetpotato. Ann Bot-London. 2000;85:191 - 196.

5. Wang $\mathrm{H}$. The breeding of sweetpotatoes for human consumption. In. Ruber LV, ID. Briggs (Ed). Sweetpotato. Proceeding of the First International Symposium. AVDRC Publication.1982;82-172.

6. Martin FW. Analysis of the Incompatibility and Sterility of Sweet Potato. In R.L. Villwereal and T.D. Griggs (Eds), Sweetpotato (AVRDC). Proceedings of the First International Symposium. 1982; $275-311$.

7. Lestari SU. Pengaruh Inkompatibilitas dan Sterilitas terhadap Pembentukan Kapsul dan Biji Ubijalar. Agrivita. 2010;32(1):19 28.

8. Acquaah G. Principles of Plant Genetics and Breeding. United Kingdom (GB): Blackwell; 2007.

9. Indriani FC, Ashari S, Basuki N, Jusuf M. Normal seedlings as A New Parameter for Predicting Cross-Incompatibility Level on Sweetpotato. Agrivita Journal of Agricultural Science. 2017;39(10):56 - 65.

10. Basuki N. Pendugaan parameter genetik dan hubungan antara hasil dengan beberapa sifat agronomis serta analisis persilangan dialel pada ubijalar [Ipomoea batatas (L.) Lam.]. Disertasi. Program Pascasarjana. IPB. Bogor hal.1986;139.

11. Onwueme IC. The tropical tuber crops (Yam, Cassava, Sweetpotato, Cocoyams). John Wiley and Sons Ltd. London. 1978;234.

12. Mutasa W, Gasura E, Mabasa S, Masekesa RT, Masvodza DR. Does 2,4dichlorophenoxyacetic acid induce flowering in sweetpotato? African Journal of Biotechnology. 2013;12(51):7057 7062.

13. Susanto FA, Sulasmi ES, Dan St. A. Rahayuningsih. Pollen morphology and sucrose giving on stigma relation with incompatibility of sweetpotato [Ipomoea batatas (L.) Lam.]. The Journal of Tropical Life Science. 2013;3(3):207-211.

Available:http://www.jtrolwas.ub.ic.id/index. php/jtrolwas/article/view/92.

14. Martin FW. The system of selfincompatibility in Ipomoea. The Journal of Heredity. 1968; 59(5):262 - 267.

15. Jones A. Sweetpotato. p. 645 - 655. In W.R. Fehr. and H. Hadley (Eds.). Hybridization of crop plants. American Society of Agronomy-Crop Science Society of America; 1980.

Available:http://doi.org/10.2135/1980.

Hybridization of crops.c46.

16. Martin FW, Cabanillas E. Post-pollen germination barriers to seed set insweetpotato.Euphytica. 1966;15(3),404411.

Available:http://doi.org/10.1007/BF000221 87.

17. Jayasuriya KMG, Baskin JM, Geneve RL, Baskin CC. Morphology and anatomy of physical dormancy in Ipomoea lacunose: 
Identification of the water gap in seeds of Convolvulaceae (Solanales). Annals of Botany. 2007;100:13-22.

DOI: $10.1093 / \mathrm{aob} / \mathrm{mcm} 070$,

Available: www.aob.oxfordjournals.org.

18. Martin FW, Ortiz S. Anatomy of the stigma and style of sweetpotato. New Phytol. 1967;66:109 - 113 .

19. Martin FW. Sterility in some species related to the sweetpotato. Euphytica. 1970;19:459 - 464.

20. Gasura E, Mashingaidze AB, Mukasa SB. Genetic variability for tuber yield, quality, virus disease complex traits in Uganda sweetpotato germplasm. Afr Crop Sci J. 2008;16:147-160.

21. Nasrallah JB, Nasrallah ME. Pollen-stigma signaling in the sporophytic self- incompatibility response. The Plant Cell. 1993;(5):1325 - 1335.

22. Gurmu F, Hussein S, Laing M. Self and cross-incompatibilities in sweetpotato and their implications on breeding. AJCS. 2013;7(13):2074 - 2078.

23. Filho JM. 2015. Seed vigor testing: An overview of the past, present and future perspective. Scientia Agricola. 2015; 72(4):363-374.

Available:http://doi.org/10.1590/01039016-2015-0007.

24. Onyimba IA, Ogbonna Al, Egbere JO, Njila HL, Ogbonna CIC. Bioconversion of Sweet Potato Leaves to Animal Feed. Annual Research \& Review in Biology. 2015;8(3):1-6.

DOI: $10.9734 / A R R B / 2015 / 19$

(c) 2021 Indriani et al.; This is an Open Access article distributed under the terms of the Creative Commons Attribution License (http://creativecommons.org/licenses/by/4.0), which permits unrestricted use, distribution, and reproduction in any medium, provided the original work is properly cited. http://www.sdiarticle4.com/review-history/68071 